Article

\title{
Selective suppression of toluene formation in solvent-free benzyl alcohol oxidation using supported Pd-Ni bimetallic nanoparticles
}

\author{
Jianwei Che a, Mengjia Hao a, Wuzhong Yi a, Hisayoshi Kobayashi b, Yuheng Zhoua, Liping Xiao a, \\ Jie Fan ${ }^{\mathrm{a}, *}$ \\ a Key Lab of Applied Chemistry of Zhejiang Province, Department of Chemistry, Zhejiang University, Hangzhou 310027, Zhejiang, China \\ ${ }^{\mathrm{b}}$ Department of Chemistry and Materials Technology, Kyoto Institute of Technology, Kyoto 606-8585, Kyoto Prefecture, Japan
}

\section{A R T I C L E I N F O}

\section{Article history:}

Received 12 July 2017

Accepted 13 August 2017

Published 5 November 2017

\section{Keywords:}

Palladium-nickel

Bimetallic nanoparticle

Benzyl alcohol

Toluene

Solvent-free

Oxidation

\section{A B S T R A C T}

The solvent-free oxidation of benzyl alcohol was studied using supported Pd-Ni bimetallic nanoparticles. Compared with monometallic Pd, the addition of Ni to Pd was found to be effective in suppressing the nondesired product toluene, thereby enhancing the selectivity towards benzaldehyde. This result was attributed to a dual effect of $\mathrm{Ni}$ addition: the weakening of dissociative adsorption of benzyl alcohol and the promotion of oxygen species involved in the oxidation pathway.

(C) 2017, Dalian Institute of Chemical Physics, Chinese Academy of Sciences. Published by Elsevier B.V. All rights reserved.

\section{Introduction}

Selective oxidation of alcohols to corresponding aldehydes or ketones is of fundamental importance in functional group transformation in both laboratorial and industrial applications. Traditionally, alcohol oxidations are performed by using stoichiometric and toxic permanganate or chromate as oxidants. From the viewpoint of green chemistry, the liquid-phase oxidation of alcohols with molecular oxygen or air as oxidants under mild solvent-free reaction conditions is highly desirable.

Over the past few years, a variety of heterogeneous catalysts have been developed for this transformation [1,2]. Among the reported catalysts, supported palladium has been recognized as one of the best catalysts owing to its excellent activity [3-7].
Although supported palladium catalysts can be very active for the oxidation of benzyl alcohol, which is a model reaction for selective oxidation, the selectivity towards the desired product benzaldehyde is difficult to control. Previous investigations on the solvent-free oxidation of benzyl alcohol using palladium catalysts have demonstrated the formation of many products, including (a) benzaldehyde, benzoic acid, and benzyl benzoate from oxidation, dehydrogenation, and esterification, respectively (b) benzene from decarbonylation, (c) dibenzyl ether from dehydration, (d) dibenzyl acetal from condensation, and (e) toluene from disproportionation or hydrogenolysis of benzyl alcohol [8-10]. Among these products, toluene is the major byproduct under solvent-free conditions, which can lower the selectivity towards the oxidation product [6,7]. To switch off

\footnotetext{
* Corresponding author. Tel/Fax: +86-571-87952338; E-mail: jfan@zju.edu.cn

This work was supported by National Natural Science Foundation of China (21271153, 21373181, 21222307, U1402233), Major Research Plan of National Natural Science Foundation of China (91545113), and the Fundamental Research Funds for the Central Universities (2014XZZX003-02). DOI: 10.1016/S1872-2067(17)62904-8 | http://www.sciencedirect.com/science/journal/18722067 | Chin. J. Catal., Vol. 38, No. 11, November 2017
} 
toluene formation and achieve high aldehyde selectivity, one widely adopted approach is to use intrinsically basic or modified supports. Sankar et al. [9] reported $\mathrm{MgO}$ - and ZnO-supported catalysts did not produce any toluene. They interpreted that the basicity of the supports inhibited the cleavage of the $\mathrm{C}-\mathrm{O}$ bond of benzyl alcohol that gives rise to toluene generation. Furthermore, N-doped mesoporous carbon [11], amino-group-functionalized TUD-1 and CNT [12,13], and alkali-treated titanate nanobelts [14] also showed enhanced selectivity towards the desired oxidation product owing to the basic sites grafted on the surface of the supports. Another approach to suppress toluene formation involves the use of supported bimetallic or trimetallic catalysts. Pd-Au bimetallic nanoparticles are most frequently used, which improve the overall selectivity compared with monometallic Pd [15]. However, a considerable amount of toluene is inevitably formed when it comes to a higher reaction temperature or conversion $[9,16]$. Recently, He et al. [17] demonstrated that the addition of Pt to the Pd-Au alloy catalysts could significantly minimize toluene formation. However, the full complexity of ternary alloys can be missed because the composition of such catalysts varies systematically with particle size.

It is generally accepted that bimetallic catalysts exhibit superior catalytic performance to monometallic catalysts owing to the synergetic interactions between the metals [18-20]. In terms of selectivity control, the introduction of a less active metal to a more active metal may selectively nullify some active sites for side reactions [21]. In the case of Pd-Au bimetallic catalysts, the catalytically more active Pd is perturbed by the inferior activity of $\mathrm{Au}$, which makes Pd more atomic-like and suppresses the formation of byproducts [22]. Additionally, analogous $\mathrm{Pd}-\mathrm{M}$ ( $\mathrm{M}=\mathrm{Co}, \mathrm{Cu}, \mathrm{Zn}, \mathrm{Ga}, \mathrm{Ag}, \mathrm{Sn}, \mathrm{Pb}, \mathrm{Bi}$ ) catalysts have been used in many $\mathrm{Pd}$-catalyzed reactions and has resulted in enhanced selectivity [23-29]. For example, Pd-Ag and Pd-Cu bimetallic nanoparticles dramatically increased the selectivity towards the target alkenol in the semi-hydrogenation of alkynol reported by Yarulin et al. [24]. In an attempt to prevent the formation of nonselective reaction products, especially toluene, in solvent-free benzyl alcohol oxidation, we adopted a bimetallic catalysis strategy by alloying $\mathrm{Pd}$ with nonprecious transition metals instead of other noble metals such as $\mathrm{Au}$ and Pt. Herein, we report that a Pd-Ni bimetallic catalyst displayed high selectivity and overall productivity to the corresponding aldehyde.

\section{Experimental}

\subsection{Catalyst preparation}

\subsubsection{Synthesis of EP-FDU-12}

The EP-FDU-12 support was synthesized as reported in the literature [30]. Typically, $0.50 \mathrm{~g}$ of Pluronic F127, $0.60 \mathrm{~g}$ of 1,3,5-trimethylbenzene (TMB), and $1.25 \mathrm{~g}$ of $\mathrm{KCl}$ were dissolved in $50 \mathrm{~mL}$ of $\mathrm{HCl}(1 \mathrm{~mol} / \mathrm{L})$ at $14 \pm 0.1{ }^{\circ} \mathrm{C}$. After stirring for $1 \mathrm{~h}, 2.08 \mathrm{~g}$ of tetraethyl orthosilicate (TEOS) was added to this solution. After stirring at $14{ }^{\circ} \mathrm{C}$ for $24 \mathrm{~h}$, the mixture was transferred into an autoclave and heated at $140{ }^{\circ} \mathrm{C}$ for $24 \mathrm{~h}$. The product was obtained by filtration and dried at room temperature in air. The organic templates were removed by annealing at $350{ }^{\circ} \mathrm{C}$.

\subsubsection{Synthesis of Pd nanoparticles}

Pd nanoparticles (PdNPs) were synthesized according to a reported method [31]. In a typical synthesis, $112 \mathrm{mg}$ of palladium acetate was mixed with $3.3 \mathrm{~mL}$ of oleic amine with stirring at $50{ }^{\circ} \mathrm{C}$ to form a clear solution. Oleic acid (3.2 mL) was then added and the mixture was kept at $50{ }^{\circ} \mathrm{C}$ for $1 \mathrm{~h}$. Then, 386 $\mathrm{mg}$ of tetrabutylammonium borohydride (TBAB) dissolved in 2 $\mathrm{mL}$ of $\mathrm{CHCl}_{3}$ was added in one portion. The mixture was heated for $1 \mathrm{~h}$ before it was cooled to room temperature. The PdNPs were precipitated by the addition of $15 \mathrm{~mL}$ of ethanol. The precipitate was separated by centrifugation and washed with ethanol. Finally, the precipitate was dried in a vacuum oven overnight. The size of the PdNPs was examined by transmission electron microscopy (TEM) and determined to be $2.83 \pm 0.27$ nm.

\subsubsection{Synthesis of supported Pd-Ni bimetallic nanoparticles}

The synthesis of supported Pd-Ni bimetallic nanoparticles (BMNPs) was similar to our previous study with some modifications [32]. First, the required amount of nickel nitrate and $500 \mathrm{mg}$ of mesoporous silica (EP-FDU-12) were added to $5 \mathrm{~mL}$ of ethanol. The mixture was stirred until the ethanol evaporated to form a powder, which was further dried under vacuum oven overnight. The as-obtained solid powder was added to a predetermined volume of a chloroform solution of PdNPs. After $24 \mathrm{~h}$ of stirring, the solid product was centrifuged and dried in air. Finally, the powder was calcinated under $5 \% \mathrm{H}_{2} / 95 \% \mathrm{Ar}$ at $500{ }^{\circ} \mathrm{C}$ for $4 \mathrm{~h}$. The loading mass of Pd was $1 \mathrm{wt} \%$ for all the samples. For comparison, supported monometallic $\mathrm{Pd}$ and $\mathrm{Ni}$ nanoparticles were prepared in a similar manner to the above procedure by omitting the deposition of nickel nitrate and PdNPs, respectively.

\subsection{Characterizations}

The TEM images were recorded on a Hitachi HT-7700 operated at $80 \mathrm{kV}$. High angle annular dark field scanning transmission electron microscopy (HAADF-STEM) and energy dispersive X-ray spectrometry (EDX) analysis were performed on a Tecnai G2 F20 operated at $200 \mathrm{kV}$. The sample was embedded in epoxy resin and then microtomed into a sub-100-nm ultrathin film at room temperature. These thin film samples floated on water or other solvents and were collected by a copper mesh with a polymer microgrid for HAADF-STEM imaging and elemental line scanning. X-ray diffraction (XRD) patterns were recorded on a Rigaku Ultima IV with $\mathrm{Cu} K_{\alpha}$ radiation. X-ray photoelectron spectroscopy (XPS) measurements were performed in a VG Scientific ESCALAB Mark II spectrometer equipped with two ultra-high vacuum (UHV) chambers. All binding energies were referenced to the $\mathrm{C} 1 \mathrm{~s}$ peak at $284.8 \mathrm{eV}$ of the surface adventitious carbon. Diffuse reflectance Fourier transform infrared spectra of adsorbed CO (CO-DRIFT) were obtained on a Bruker Vertex 70 spectrometer equipped with a 
mercury-cadmium-tellurium (MCT) detector, a diffuse reflectance accessory, and a Harrick HVC-DRP cell. The sample loaded into the cell was purged with flowing argon $(20 \mathrm{~mL} / \mathrm{min})$ and a spectrum was recorded as a background. Then, the CO adsorption on the sample was performed at room temperature by switching the gas flow to $\mathrm{CO}(20 \mathrm{~mL} / \mathrm{min})$ and then argon $(20 \mathrm{~mL} / \mathrm{min})$. All the spectra were recorded with 64 scans at a $4 \mathrm{~cm}^{-1}$ resolution.

\subsection{Catalytic reaction}

Benzyl alcohol oxidation was carried out in a $50 \mathrm{~mL}$ glass stirred reactor. In a typical reaction, $20 \mathrm{mg}$ of catalyst and $3 \mathrm{~g}$ ( $27.7 \mathrm{mmol}$ ) of benzyl alcohol were charged into the reactor, which was then purged with gas $\left(\mathrm{O}_{2}, \mathrm{H}_{2}\right.$, or $\left.\mathrm{N}_{2}\right)$ three times before closing. The pressure was maintained at $0.1 \mathrm{MPa}$ (relative pressure) by connecting the reactor to a gas line to ensure that any consumed gas was replenished. The mixture was then heated and stirred vigorously at $120^{\circ} \mathrm{C}$ in an oil bath. After a specific time, the stirring was stopped and the reactor was immediately cooled in an ice bath. After cooling to room temperature, the solid catalyst was removed by centrifugation and the organic products were analyzed by a gas chromatograph (FuLi GC-9790) equipped with a KB-5 capillary column and a FID detector. The structures of the products were confirmed by comparison with standard samples and by GC-MS (Shimadzu GCMS-QP2010). A standard normalization method was used to quantify the composition of the reaction mixtures. The conversion of benzyl alcohol and product selectivity were calculated using the following equations:

$$
\begin{gathered}
\text { Conversion }(\%)=A_{\mathrm{p}} /\left(A_{\mathrm{r}}+A_{\mathrm{p}}\right) \times 100 \\
\text { Selectivity for } i(\%)=A_{i} / A_{\mathrm{p}} \times 100
\end{gathered}
$$

in which $A$ is the corrected FID chromatographic peak area, and $\mathrm{r}, \mathrm{p}$, and $i$ represent benzyl alcohol, all the products, and a certain product, respectively.

\subsection{Density functional theory calculations}

Density functional theory (DFT) calculations were carried out using a plane-wave-based program, Castep [33,34]. Model clusters, $\mathrm{Pd}_{25}$ and $\mathrm{Ni}_{21} \mathrm{Pd}_{4}$, were used in the calculations. Whole structures were truncated from $\mathrm{Pd}$ and $\mathrm{Ni}$ crystals along the (111) orientation. For $\mathrm{Ni}_{21} \mathrm{Pd}_{4}$, the central four $\mathrm{Ni}$ atoms were replaced by $\mathrm{Pd}$ atoms. The lattice constants of the unit cell were $a=b=2 \mathrm{~nm}, c=3 \mathrm{~nm}$, and $\alpha=\beta=\gamma=90^{\circ}$. The direction of the $c$-axis includes the vacuum region. Only the central four atoms and adsorbate were optimized. The Perdew-Burke-Ernzerhof (PBE) functional $[35,36]$ was used together with the ultrasoft-core potentials [37]. The basis set cutoff energies were set to $300 \mathrm{eV}$ for geometry optimization, and $340 \mathrm{eV}$ for the energy re-evaluation. The electron configurations of the atoms were: $\mathrm{H}, 1 s^{1} ; \mathrm{C}, 2 s^{2} 2 p^{2} ; \mathrm{O}, 2 s^{2} 2 p^{4} ; \mathrm{Ni}, 3 d^{8} 4 s^{2} ;$ and $\mathrm{Pd}, 4 d^{10}$.

\section{Results and discussion}

Supported Pd-Ni BMNPs were initially synthesized as an example of bimetallic catalysts. We prepared Pd-Ni BMNPs loaded on mesoporous silica (EP-FDU-12) by a general solid-state alloying method according to our previous study [32]. In brief, nickel nitrate was first loaded onto EP-FDU-12 by impregnation, and then colloidal Pd nanoparticles were deposited on the support as a seed for nickel growth before high-temperature reduction and solid-state alloying. The as-synthesized bimetallic catalysts with different Ni/Pd molar ratios in the precursors are denoted as $\operatorname{Pd}_{1} \mathrm{Ni}_{x}(x=1-20)$. The overall compositions of the bimetallic catalysts were confirmed by ICP-MS analysis. As shown in Table 1, the actual Ni/Pd molar ratios were slightly lower than the nominal ratios. Electron microscopy techniques were employed to reveal the morphology and structure of the Pd-Ni bimetallic catalysts. The particle size distributions of the monometallic Pd and bimetallic Pd-Ni samples were obtained by TEM, as depicted in Fig. 1. The TEM images show that the Pd nanoparticles in Pd/EP-FDU-12 were mostly at the outer edge of the mesoporous channels, whereas Pd-Ni BMNPs were uniformly dispersed in the EP-FDU-12 channels. This suggested that interparticle heteroatom migration occurred between Pd nanoparticles on the periphery and Ni clusters in the inner channels during the solid-state alloying process. The corresponding particle size distribution for each sample reveal that the average particle size was approximately $5.8 \mathrm{~nm}$ for monometallic Pd catalyst and 6.3 and $6.5 \mathrm{~nm}$ for the $\mathrm{Pd}_{1} \mathrm{Ni}_{5}$ and $\mathrm{Pd}_{1} \mathrm{Ni}_{20}$, respectively, for the bimetallic catalysts. These slight differences in the overall particle size distributions could rule out the effect of the particle size on the catalytic performances.

To confirm the formation of the bimetallic nanoparticles, HRTEM, HAADF-STEM, and EDX analysis were employed. Fig. 2(a) presents a HRTEM image of an individual Pd-Ni BMNP from a $\mathrm{Pd}_{1} \mathrm{Ni}_{5}$ sample. The lattice fringes of $\mathrm{Pd}_{1} \mathrm{Ni}_{5}$ display a fcc crystalline structure with interplanar spacings of $0.210 \mathrm{~nm}$ in the particle, which is between the interplanar spacing of pure $\mathrm{Pd}(0.224 \mathrm{~nm})$ and pure $\mathrm{Ni}(0.203 \mathrm{~nm})$ particles. Thus, the $\mathrm{Ni} / \mathrm{Pd}$ molar ratio calculated according to Vegard's law is $2 / 1$, which is lower than the actual ratio of $4.2 / 1$ obtained by ICP analysis. This is mainly because some monometallic Ni clusters formed through self-nucleation and growth when there were no PdNPs nearby. Direct evidence of a bimetallic structure was also obtained from STEM-EDX line scanning. As shown in Fig. 2(b) and (c), the composition line scan profiles of $\mathrm{Pd}$ and $\mathrm{Ni}$ cross a representative $\mathrm{Pd}_{1} \mathrm{Ni}_{5}$ particle and show a similar intensity distribution over both elements, which confirmed the presence of both metals in the BMNPs with no signs of segregation.

The formation of bimetallic nanoparticles was further confirmed by XRD. As shown in Fig. 3, monometallic Pd exhibited two peaks at $2 \theta$ values of $40.1^{\circ}$ and $46.7^{\circ}$, corresponding to the

Table 1

Bulk compositions of catalysts obtained using ICP-MS.

\begin{tabular}{lccc}
\hline Catalyst & $\begin{array}{c}\text { Ni loading } \\
\text { (wt\%) }\end{array}$ & $\begin{array}{c}\text { Pdloading } \\
\text { (wt\%) }\end{array}$ & $\begin{array}{c}\text { Actual Ni/Pd } \\
\text { molar ratios }\end{array}$ \\
\hline $\mathrm{Pd} / \mathrm{FDU}$ & 0 & 0.98 & - \\
$\mathrm{Pd}_{1} \mathrm{Ni}_{5} / \mathrm{FDU}$ & 2.36 & 1.03 & $4.2 / 1$ \\
$\mathrm{Pd}_{1} \mathrm{Ni}_{20} / \mathrm{FDU}$ & 10.89 & 1.05 & $18.8 / 1$ \\
\hline
\end{tabular}



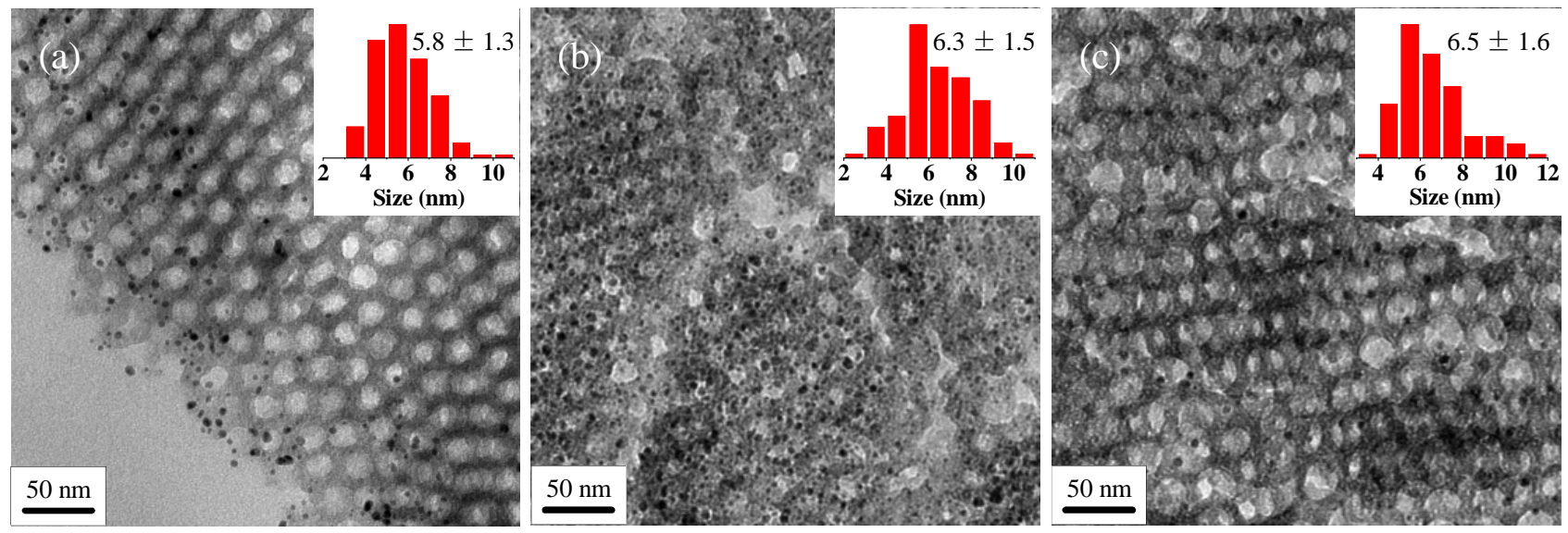

Fig. 1. TEM images of (a) Pd/FDU, (b) $\mathrm{Pd}_{1} \mathrm{Ni}_{5} / \mathrm{FDU}$, and (c) $\mathrm{Pd}_{1} \mathrm{Ni}_{2} / \mathrm{FDU}$ (insets: particle size distribution).
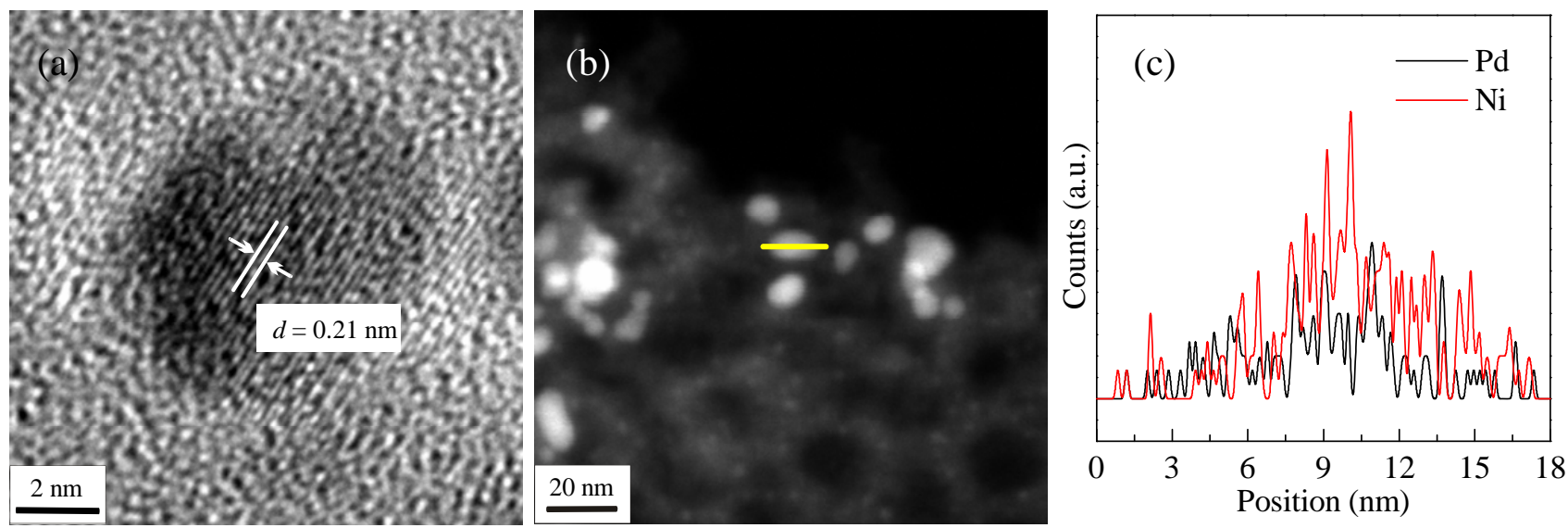

Fig. 2. (a) HRTEM image, (b) HAADF-STEM image, and (c) the corresponding line scan profiles of $\mathrm{Pd}_{1} \mathrm{Ni}_{5} / \mathrm{FDU}$.

(111) and (200) reflections of Pd (PDF\# 46-1043), respectively. The diffraction peaks of the bimetallic Pd-Ni samples were shifted to higher $2 \theta$ values of $41.0^{\circ}$ and $47.7^{\circ}$ relative to the original peaks of monometallic Pd, suggesting that lattice contraction occurred as a result of substitution of the Pd atoms by $\mathrm{Ni}$ atoms. Furthermore, individual $\mathrm{Ni}$ diffraction peaks were observed in the XRD pattern of the $\mathrm{Pd}_{1} \mathrm{Ni}_{20}$ sample, indicating

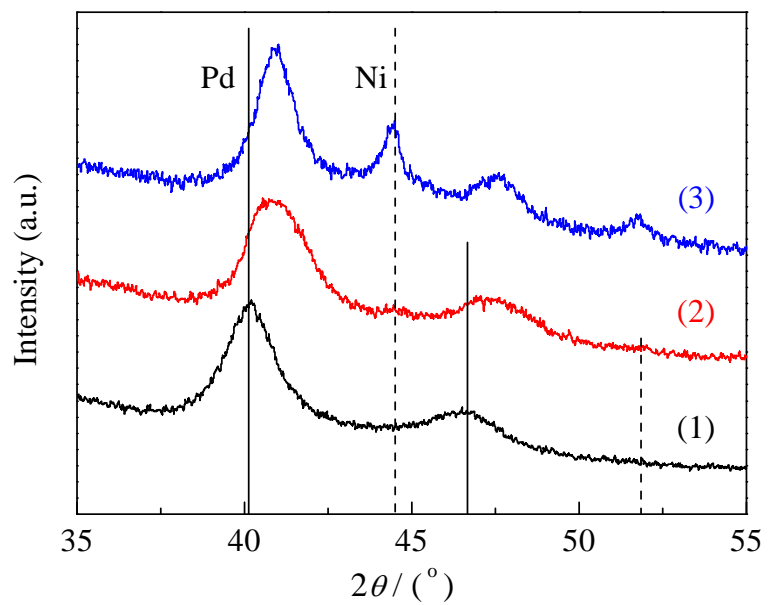

Fig. 3. XRD patterns of $\mathrm{Pd} / \mathrm{FDU}(1), \mathrm{Pd}_{1} \mathrm{Ni}_{5} / \mathrm{FDU}(2)$, and $\mathrm{Pd}_{1} \mathrm{Ni}_{20} / \mathrm{FDU}$ (3). the formation of monometallic Ni particles at high Ni loadings.

The surface composition and electronic properties of BMNPs were analyzed by XPS measurements. The spectra of Pd $3 d$ and Ni $2 p$ core levels are shown in Fig. 4 , and the surface compositions are summarized in Table 2. As shown in Fig. 4(a), the monometallic Pd $3 d$ spectra display a typical doublet, $3 d_{5 / 2}$ (335.9 eV) and $3 d_{3 / 2}(341.1 \mathrm{eV})$, which can be deconvoluted into four peaks corresponding to $\mathrm{Pd}^{0}$ and $\mathrm{Pd}^{2+}$. The appearance of $\mathrm{Pd}^{2+}$ peaks may originate from the partial oxidation of the $\mathrm{Pd}$ surface. However, the $\mathrm{Pd}^{0}$ percentage increased from $71 \%$ to $81 \%$ from monometallic $\mathrm{Pd}$ to bimetallic $\mathrm{Pd}_{1} \mathrm{Ni}_{20}$, which suggested that the higher oxidizing ability of Ni restricted the oxidation of Pd [38]. For bimetallic Pd-Ni samples, representative Pd $3 d$ peaks shifted slightly (ca. $0.1-0.3 \mathrm{eV}$ ) to a lower binding energy (BE) with increasing Ni loading, in accordance with previous reports $[39,40]$. It has been reported that BE shifts in BMNPs are caused by both changes to the electron density and lattice disturbance [41]. In Pd-Ni BMNPs, the lattice contraction of the $\mathrm{Pd}$ atoms that resulted from the inclusion of $\mathrm{Ni}$ atoms leads to higher BE shifts. Therefore, it partially counteracts the effect of the change in the electron density of Pd, which makes the overall BE shifts in the Pd $3 d$ spectra relatively small. Nonetheless, the slight negative shift suggests the modification of the electronic structure of Pd owing to electron transfer from Ni to Pd. The Ni $2 p$ spectra of the BMNPs in Fig. 4(b) show the 


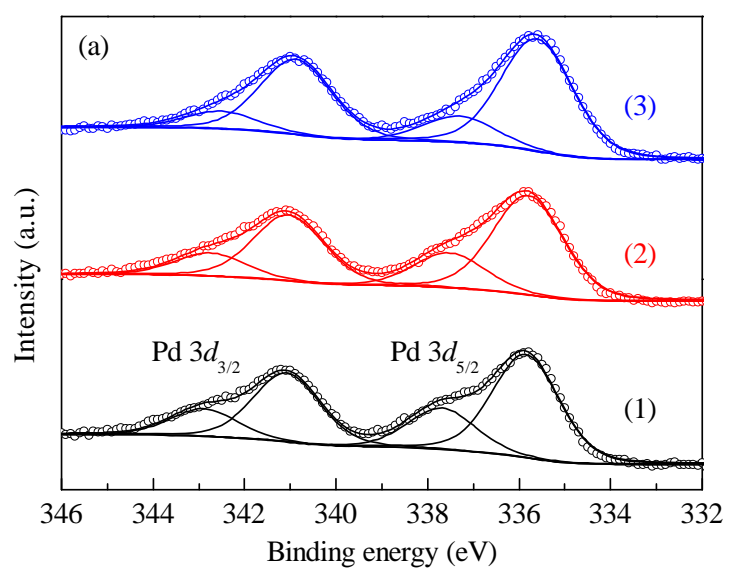

Fig. 4. XPS spectra of Pd/FDU (1), $\mathrm{Pd}_{1} \mathrm{Ni}_{5} / \mathrm{FDU}(2)$, and $\mathrm{Pd}_{1} \mathrm{Ni}_{20} / \mathrm{FDU}$ (3). (a) Pd $3 d$; (b) Ni $2 p$.

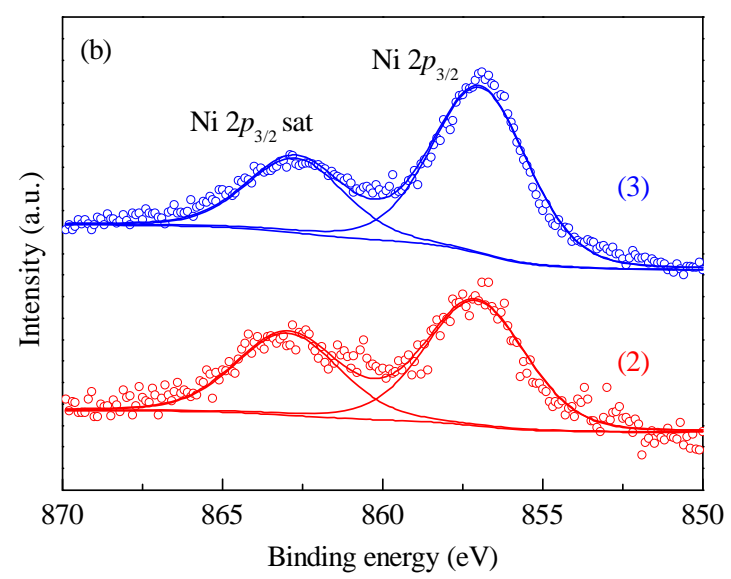

catalyst achieved the highest conversion of $89.3 \%$ at $120{ }^{\circ} \mathrm{C}$ within $4 \mathrm{~h}$. However, the selectivity to benzaldehyde was rather low (58.3\%), which was mainly owing to the formation of toluene as the major byproduct. Although the addition of Ni to Pd decreased the activity, it is obvious that all the Pd-Ni bimetallic catalysts exhibited high selectivity towards benzaldehyde (75.0\%-88.2\%) owing to the effective termination of toluene formation. Therefore, improved benzaldehyde productivity was achieved over Pd-Ni bimetallic catalysts except for $\mathrm{Pd}_{1} \mathrm{Ni}_{20}$. The lower activity and productivity of $\mathrm{Pd}_{1} \mathrm{Ni}_{20}$ can be ascribed to the presence of Ni particles, as revealed by XRD. Because the monometallic Ni catalyst exhibited a low benzyl alcohol conversion (8.5\%), excess Ni nanoparticles may block the active sites of Pd, leading to decreased activities. Therefore, high activity and low selectivity towards toluene can be obtained by incorporating an appropriate amount of $\mathrm{Ni}$ into the Pd catalyst.

The effect of the Ni/Pd molar ratio on the catalytic selectivity of benzyl alcohol oxidation was further investigated by comparing products distributions at isoconversion levels. As shown in Fig. 5(a), at an isoconversion of $10 \%$, the toluene selectivity significantly reduced whereas the benzaldehyde selectivity was improved with the increased addition of Ni. The same trend on the toluene selectivity was observed at a higher isoconversion of $80 \%$ (Fig. 5(b)). The selectivity towards toluene was reduced from $22.6 \%$ over monometallic Pd to $1.6 \%$

Table 3

Catalytic performances of monometallic Pd and Ni catalysts and Pd-Ni bimetallic catalysts a .

\begin{tabular}{|c|c|c|c|c|c|c|c|}
\hline \multirow{2}{*}{ Catalyst } & \multirow{2}{*}{ Conversion (\%) } & \multicolumn{5}{|c|}{ Selectivity (\%) } & \multirow{2}{*}{$\begin{array}{c}\text { Benzaldehyde productivity } \\
\text { (mol/(g.h)) }\end{array}$} \\
\hline & & Toluene & Benzaldehyde & Benzoic acid & Benzyl benzoate & Others $^{b}$ & \\
\hline$\overline{P d}$ & 89.3 & 24.2 & 58.3 & 13.4 & 2.5 & 1.6 & 180 \\
\hline $\mathrm{Pd}_{1} \mathrm{Ni}_{1}$ & 76.0 & 16.1 & 75.0 & 4.7 & 2.8 & 1.4 & 198 \\
\hline $\mathrm{Pd}_{1} \mathrm{Ni}_{5}$ & 76.6 & 3.4 & 88.2 & 4.1 & 1.7 & 2.6 & 234 \\
\hline $\mathrm{Pd}_{1} \mathrm{Ni}_{10}$ & 74.8 & 3.5 & 82.9 & 7.8 & 3.7 & 2.1 & 215 \\
\hline $\mathrm{Pd}_{1} \mathrm{Ni}_{20}$ & 48.3 & 2.2 & 86.6 & 5.3 & 2.5 & 3.4 & 145 \\
\hline $\mathrm{Ni}^{\mathrm{d}}$ & 8.5 & 0.0 & 95.0 & 0.0 & 5.0 & 0.0 & 28 \\
\hline
\end{tabular}

a Reaction conditions: benzyl alcohol $3 \mathrm{~g}$; catalyst $20 \mathrm{mg} ; \mathrm{O}_{2} 0.1 \mathrm{MPa}$; temperature $120^{\circ} \mathrm{C}$; time $4 \mathrm{~h}$

b Other products including benzene, dibenzyl ether, and dibenzyl acetal.

c Calculated after a $4 \mathrm{~h}$ reaction.

d Same loading mass (2.4 wt $\%)$ as $\mathrm{Ni}$ in $\mathrm{Pd}_{1} \mathrm{Ni}_{5}$. 

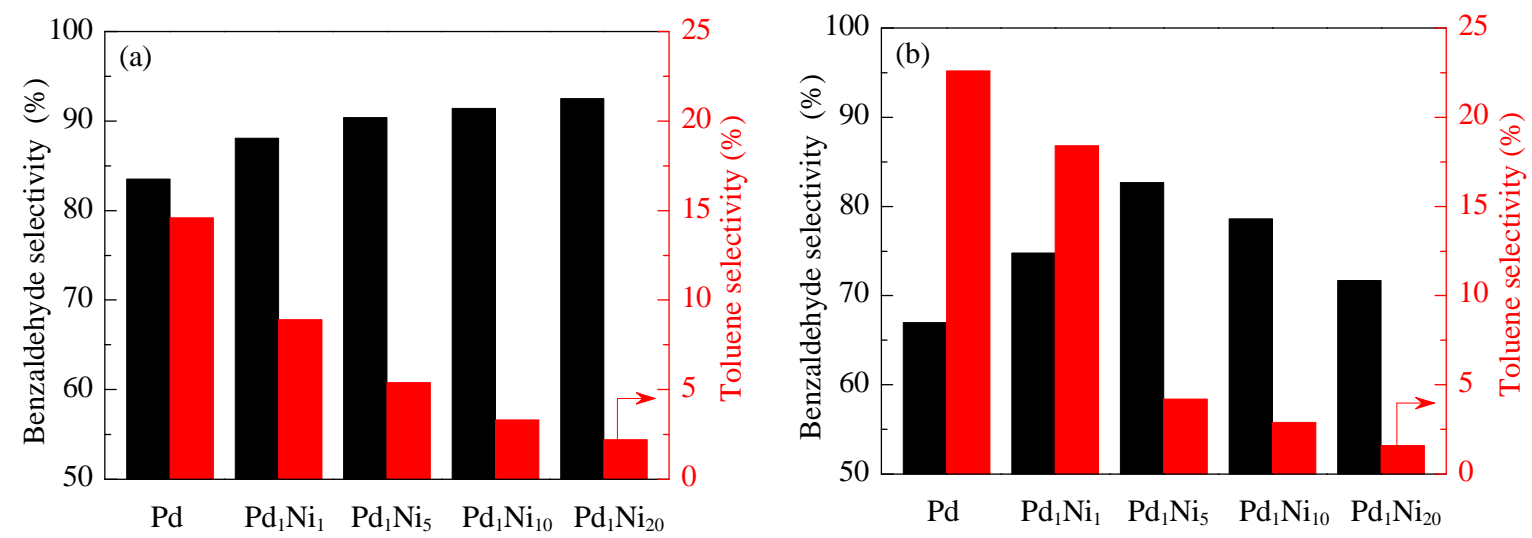

Fig. 5. Comparison of benzaldehyde and toluene selectivity at isoconversions of (a) $10 \%$ and (b) $80 \%$ between monometallic Pd and Pd-Ni bimetallic catalysts. Reaction conditions: benzyl alcohol $3 \mathrm{~g}$; catalyst $20 \mathrm{mg} ; \mathrm{O}_{2} 0.1 \mathrm{MPa}$; temperature $120^{\circ} \mathrm{C}$.

over bimetallic $\mathrm{Pd}_{1} \mathrm{Ni}_{20}$. Furthermore, the selectivity towards benzaldehyde at $80 \%$ isoconversion increased upon the addition of $\mathrm{Ni}$ but decreased with further increase in the Ni loading amount. The decrease in the benzaldehyde selectivity mainly resulted from over-oxidation to benzoic acid, which is a facile process at high benzyl alcohol conversion. As noted earlier, the addition of more Ni lowered the activities of the bimetallic catalysts, which may lead to a gradual conversion of benzaldehyde to benzoic acid. Hence, the highest selectivity towards benzaldehyde was obtained for the $\mathrm{Pd}_{1} \mathrm{Ni}_{5}$ catalyst. Nonetheless, a higher Ni loading amount contributed to the oxidation process in which toluene formation was hardly present.

Catalytic stability is an important factor to be considered for heterogeneous catalysts. Therefore, we investigated the recycling of the $\mathrm{Pd}_{1} \mathrm{Ni}_{5}$ bimetallic catalyst. The catalyst was recovered by centrifugation after each reaction run, washed with acetone, dried at $65{ }^{\circ} \mathrm{C}$, and re-used in a subsequent run. The recyclability of the $\mathrm{Pd}_{1} \mathrm{Ni}_{5}$ sample for 4 cycles is shown in Fig. 6. The conversion dropped slightly and the selectivities towards both benzaldehyde and toluene did not change significantly. No obvious leaching of Pd and/or Ni from the catalysts was evi-

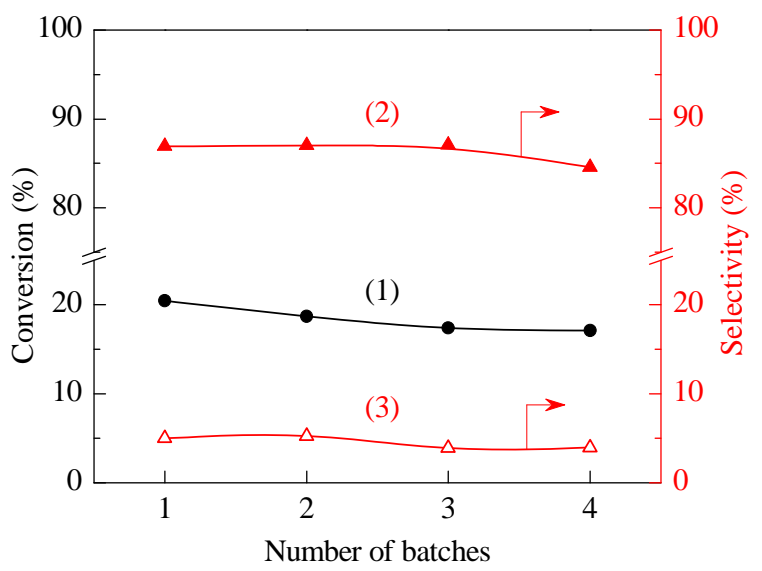

Fig. 6. Recyclability of $\mathrm{Pd}_{1} \mathrm{Ni}_{5}$ bimetallic catalyst. (1) Benzyl alcohol conversion; (2) Benzaldehyde selectivity; (3) Toluene selectivity. Reaction conditions: benzyl alcohol $3 \mathrm{~g}$; catalyst $20 \mathrm{mg} ; \mathrm{O}_{2} 0.1 \mathrm{MPa}$; temperature $120^{\circ} \mathrm{C}$; time $1 \mathrm{~h}$. dent. Therefore, the bimetallic catalyst was stable and could be readily reused.

To clarify the role of $\mathrm{Ni}$ in the bimetallic catalysts, the catalytic performances of the $\mathrm{Pd}$ monometallic catalyst and $\mathrm{Pd}_{1} \mathrm{Ni}_{5}$ bimetallic catalyst were compared. Fig. 7 shows the time-dependent conversion and selectivity of the reaction over the two catalysts. As shown in Fig. 7(a), both catalysts had a comparative activity within $0.5 \mathrm{~h}$. Thereafter, the Pd catalyst
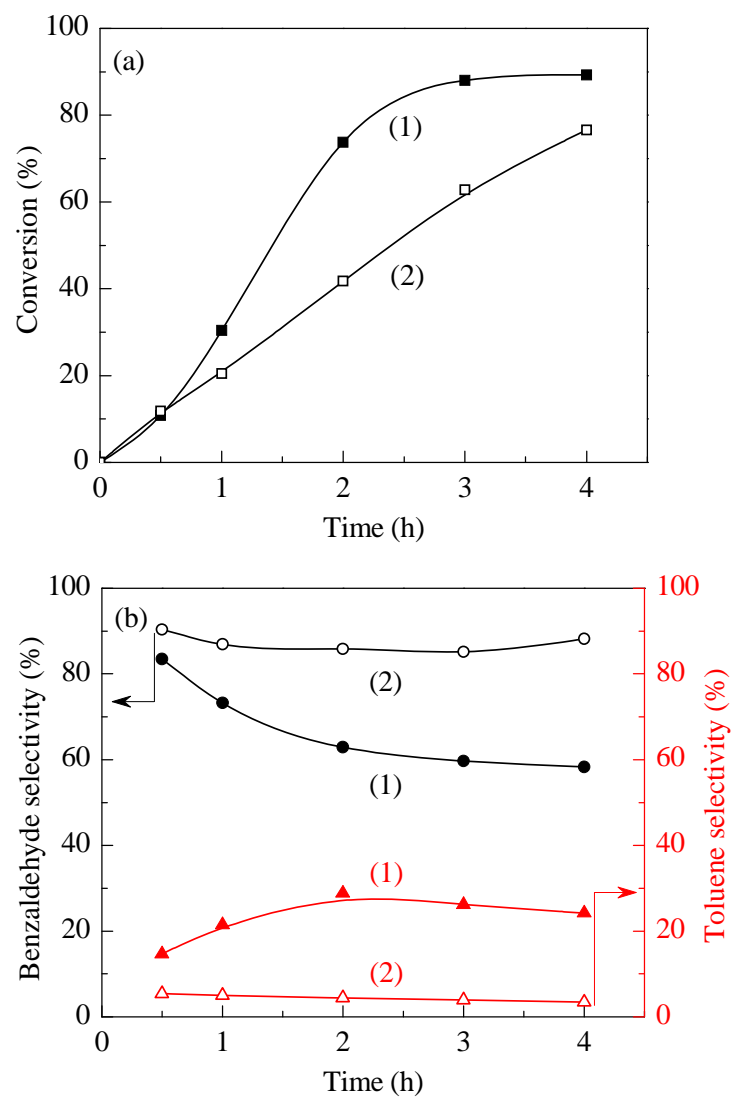

Fig. 7. Time profiles of (a) benzyl alcohol conversion and (b) benzaldehyde and toluene selectivity over monometallic $\mathrm{Pd}(1)$ and $\mathrm{Pd}_{1} \mathrm{Ni}_{5}(2)$ bimetallic catalysts. Reaction conditions: benzyl alcohol $3 \mathrm{~g}$; catalyst 20 $\mathrm{mg} ; \mathrm{O}_{2} 0.1 \mathrm{MPa}$; temperature $120^{\circ} \mathrm{C}$. 
exhibited a higher conversion rate than $\mathrm{Pd}_{1} \mathrm{Ni}_{5}$ catalyst. It appeared that the pure Pd catalyst required an induction period for re-structuring to an active form in benzyl alcohol oxidation, as previously reported [9]. This induction period was not present when $\mathrm{Ni}$ was added to $\mathrm{Pd}$, which indicated that the interaction between $\mathrm{Pd}$ and $\mathrm{Ni}$ conduces to retain the active form of Pd. With respect to selectivity (Fig. 7(b)), it is noteworthy that the selectivity towards benzaldehyde gradually decreased over monometallic Pd as a function of reaction time, whereas it was maintained above $85 \%$ over the $\mathrm{Pd}_{1} \mathrm{Ni}_{5}$ catalyst. Toluene was initially formed over both catalysts, along with benzaldehyde at low conversions and at short reaction time, suggesting it probably undergoes a pathway parallel to the oxidation process. The toluene selectivity over monometallic Pd increased up to approximately $30 \%$ in $2 \mathrm{~h}$, followed by a slight decrease owing to the formation of benzoic acid in a moderate amount. In contrast, the $\mathrm{Pd}_{1} \mathrm{Ni}_{5}$ bimetallic catalyst controlled the toluene selectivity below $5 \%$ throughout the reaction process, which implied that the Ni component integrated with Pd was stable and effectively suppressed the side reaction pathway.

It has been experimentally verified that oxygen is not required for the formation of toluene [9]. Therefore, solvent-free oxidation of benzyl alcohol under anaerobic conditions was performed using $\mathrm{Pd}$ and $\mathrm{Pd}_{1} \mathrm{Ni}_{5}$ as catalysts. The results are listed in Table 4. Under a $\mathrm{N}_{2}$ atmosphere, benzaldehyde and toluene were formed exclusively over both catalysts. These two products were generated in almost equimolar amounts, evidencing the disproportionation of benzyl alcohol. However, the $\mathrm{Pd}_{1} \mathrm{Ni}_{5}$ catalyst showed lower activity than monometallic Pd for the disproportionation reaction. This indicated that the addition of Ni probably nullified some of the Pd sites that were active for the disproportionation reaction. In addition, the slightly higher amount of benzaldehyde catalyzed by $\mathrm{Pd}_{1} \mathrm{Ni}_{5}$ was ascribed to the presence of oxygen species either from adsorbed residual $\mathrm{O}_{2}$ or from the lattice oxygen of surface nickel oxide, as revealed by XPS results. As the generation of toluene from benzyl alcohol necessarily involves the formation of a $\mathrm{C}-\mathrm{H}$ bond, surface hydrogen is considered of great importance for toluene selectivity. Therefore, a $\mathrm{H}_{2}$ atmosphere was also adopted to study this aspect. From the data in Table 4, toluene was predominantly produced through the hydrogenolysis of benzyl alcohol and more toluene was formed over pure Pd catalyst. This suggested that comparatively less surface hydrogen is involved in toluene formation when $\mathrm{Ni}$ is added to $\mathrm{Pd}$.

To further study the effect of Ni addition, CO-DRIFT spectra

\section{Table 4}

Catalytic performances of monometallic Pd and bimetallic $\mathrm{Pd}_{1} \mathrm{Ni}_{5}$ catalysts under anaerobic conditions ${ }^{\mathrm{a}}$.

\begin{tabular}{lcccc}
\hline \multirow{2}{*}{ Catalyst } & \multirow{2}{*}{ Atmosphere } & $\begin{array}{c}\text { Conversion } \\
\text { (\%) }\end{array}$ & \multicolumn{2}{c}{ Selectivity(\%) } \\
\cline { 4 - 5 } $\mathrm{Pd}$ & Under $\mathrm{N}_{2}$ & 6.3 & 51.7 & 48.3 \\
$\mathrm{Pd}_{1} \mathrm{Ni}_{5}$ & Under $_{2}$ & 2.8 & 46.6 & 53.4 \\
$\mathrm{Pd}$ & Under $\mathrm{H}_{2}$ & 25.2 & 97.3 & 2.7 \\
$\mathrm{Pd}_{1} \mathrm{Ni}_{5}$ & Under $\mathrm{H}_{2}$ & 20.4 & 92.4 & 7.6 \\
\hline
\end{tabular}

a Reaction conditions: benzyl alcohol 3 g; catalyst $20 \mathrm{mg}$; $\mathrm{N}_{2}$ or $\mathrm{H}_{2} 0.1$ $\mathrm{MPa}$; temperature $120^{\circ} \mathrm{C}$; time $5 \mathrm{~h}$.

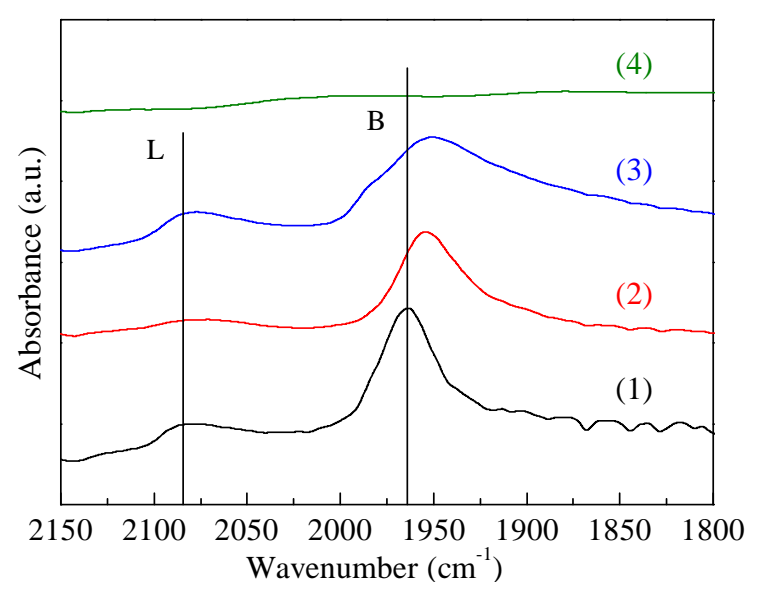

Fig. 8. DRIFT spectra of $\mathrm{CO}$ adsorbed on $\mathrm{Pd}(1), \mathrm{Pd}_{1} \mathrm{Ni}_{5}(2), \mathrm{Pd}_{1} \mathrm{Ni}_{20}(3)$, and $\mathrm{Ni}(4)$ catalysts.

of Pd, Ni and Pd-Ni samples were collected after exposure to CO then Ar. As shown in Fig. 8, two distinct bands were clearly observed for monometallic Pd. The bands at 2084 and 1964 $\mathrm{cm}^{-1}$ were assigned to linear (L) and isolated-bridged (B) CO adsorbed on the (111) facet of the Pd particles, respectively. Because the interaction between magnetic atoms and CO is rather weak $[43,44]$, no evident band was observed for the monometallic Ni sample. The Pd-Ni bimetallic catalysts exhibited spectra that were characteristic of Pd. However, a red shift of $\mathrm{B}$ band to lower frequencies (ca. $15 \mathrm{~cm}^{-1}$ ) is observed due to either a geometric or an electronic effect. On the one hand, Pd ensembles are diluted by $\mathrm{Ni}$, leading to a weaker lateral interaction between adsorbed $\mathrm{CO}$ molecules. On the other hand, the Ni-induced increase of $d$ electron density on the Pd atoms in BMNPs enhances back donation in the $2 \pi^{*}$ antibonding orbitals of adsorbed CO molecules. Both the Pd and Pd-Ni samples showed a stronger relative intensity of the $\mathrm{B}$ band than the $\mathrm{L}$ band; the relative intensities of the L bands did not vary significantly when $\mathrm{Ni}$ was added. This indicated the Pd-enrichment of the BMNPs surface, in agreement with XPS results. However, we cannot exclude the geometric effect for sure from this result. Therefore, we concluded that the synergistic interactions between Pd and Ni may affect the adsorption of benzyl alcohol on the surface of BMNPs and play a part in the catalytic selectivity.

According to previous mechanistic studies, two possible reaction pathways have been proposed for the formation of toluene, namely (a) disproportionation of benzyl alcohol and (b) hydrogenolysis of benzyl alcohol [45]. Despite different dissociation modes and adsorption states in these two pathways, both necessarily involve cleavage of the $\mathrm{C}-\mathrm{O}$ bond in benzyl alcohol and formation of the $\mathrm{C}-\mathrm{H}$ bond in toluene $[46,47]$. The DFT calculations were conducted for the $\mathrm{C}-\mathrm{O}$ bond cleavage. Fig. 9 shows the energy profiles for dissociative adsorption of benzyl alcohol on a $\mathrm{Pd}_{25}$ cluster and $\mathrm{Ni}_{21} \mathrm{Pd}_{4}$ cluster, respectively. The relative energy of the reactant on $\mathrm{Pd}_{25}(-390.3$ $\mathrm{kJ} / \mathrm{mol}$ ) was lower than that on $\mathrm{Ni}_{21} \mathrm{Pd}_{4}(-68.5 \mathrm{~kJ} / \mathrm{mol})$, which means that the adsorption of benzyl alcohol is more favorable on monometallic Pd. Although the activation energy is a con- 


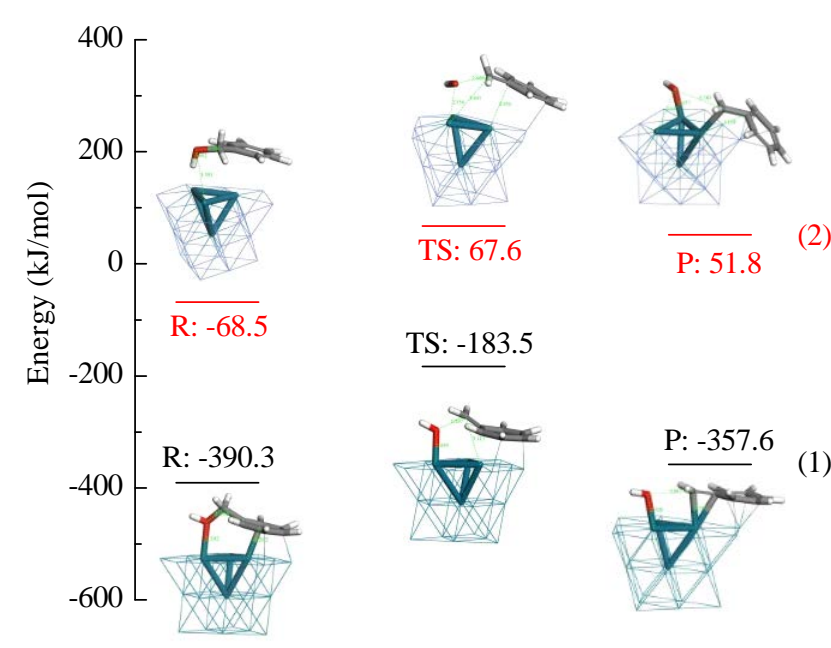

Fig. 9. Energy profiles for dissociative adsorption of benzyl alcohol on a $\mathrm{Pd}_{25}$ cluster (1) and $\mathrm{Ni}_{21} \mathrm{Pd}_{4}$ (2) cluster.

siderable amount (ca. $2 \mathrm{eV}$ ) on the $\mathrm{Pd}_{25}$ cluster, all the relative energies were below zero. Therefore, the cleavage of the $\mathrm{C}-\mathrm{O}$ bond proceeded smoothly on the $\operatorname{Pd}_{25}$ cluster. However, the product for dissociative adsorption on $\mathrm{Ni}_{21} \mathrm{Pd}_{4}$ could not be completely optimized. Although we modulated the benzyl moiety going down to the side of cluster, this configuration is not possible if the $\mathrm{Ni}_{21} \mathrm{Pd}_{4}$ structure is considered as a part of larger particles. Tentatively, a transition state (TS)-like structure was obtained between the reactant and this product. Nonetheless, the relative energies of the TS and product were above zero. Therefore, the dissociative adsorption of benzyl alcohol would hardly occur on the $\mathrm{Ni}_{21} \mathrm{Pd}_{4}$ cluster. The above calculation results can be associated with the synergistic effect of the Pd-Ni BNMPs. Previous theoretical work shows that both electronic and geometric effects will cause the degradation of surface adsorption and absorbate interaction [48]. In our case, CO-DRIFT results revealed the increase of the $d$ electron density of Pd owing to charge transfer from Ni to Pd. According to the $d$-band center theory [49], such a change in the surface electronic structure will lead to a downshift of the $d$-band center away from the Fermi level, which in turn induces weakening of the Pd-adsorbate interaction. Lower binding energies for the adsorbed molecules on the Pd-Ni bimetallic catalyst have been reported in the selective hydrogenation of 1,3-butadiene [50] and oxidation of formic acid [44]. Our DFT calculation results also confirmed the weaker adsorption of benzyl alcohol on Pd-Ni BMNPs. Moreover, Villa et al. [51] experimentally verified that there was a higher amount of benzyl alcohol on the surface of Pd than on Au-Pd by operando ATR-IR spectroscopy. Apart from electronic effects, geometric effects can also account for weakening of the dissociative adsorption of benzyl alcohol. To undergo either a disproportionation or hydrogenolysis reaction, the benzyl alcohol molecules need to adsorb on adjacent active sites. However, the geometric isolation of $\mathrm{Pd}$ active sites by $\mathrm{Ni}$ reduces the intermolecular interactions between adsorbed benzyl alcohol species, which hinders the C-O bond cleavage. Despite the Pd-enriched surface of BMNPs, the chemical composition of the surface ensembles changed. With the increased Ni loading, fewer continuous Pd ensembles were left on the surface of the BMNPs; therefore, toluene selectivity decreases accordingly, as shown by the catalysis results.

Concerning the $\mathrm{C}-\mathrm{H}$ bond formation, the oxophilicity of $\mathrm{Ni}$ could also be responsible for the suppression of toluene formation because it can scavenge the adsorbed hydrogen through oxygen species. It has been reported that the elongated interatomic distances of Pd-Pd and Pd-Ni in BMNPs increased the binding energy of oxygen [52]. Therefore, increased coverage of oxygen species over the Pd-Ni BMNPs reduces the surface hydrogen concentration, yielding more oxidation products. The results of the catalytic reaction under a $\mathrm{H}_{2}$ atmosphere also demonstrated less surface hydrogen was involved when Pd-Ni BMNPs were used. However, a high amount of Ni may also block the active sites of $\mathrm{Pd}$ and decrease the activity because $\mathrm{Ni}$ itself is less active than Pd for the oxidation reaction. Therefore, it will be more desirable to selectively suppress toluene at no cost of activity by further optimizing the bimetallic catalytic systems.

\section{Conclusions}

Supported Pd-Ni BMNPs were prepared using a solid-state alloying method. The addition of Ni to Pd enhanced the selectivity and productivity towards benzaldehyde by effectively suppressing the formation of toluene in the solvent-free benzyl alcohol oxidation reaction. We investigated the effect of adding $\mathrm{Ni}$ to Pd and demonstrated that it plays two roles. The first is weakening of the dissociative adsorption of benzyl alcohol and $\mathrm{C}-\mathrm{O}$ bond cleavage owing to the synergistic effect of $\mathrm{Pd}-\mathrm{Ni}$ BMNPs. The second role is the removal of hydrogen by the oxygen species on the $\mathrm{Ni}$ surface and inhibition of $\mathrm{C}-\mathrm{H}$ bond formation.

\section{References}

[1] T. Mallat, A. Baiker, Chem. Rev., 2004, 104, 3037-3058.

[2] S. E. Davis, M. S. Ide, R. J. Davis, Green Chem., 2013, 15, 17-45.

[3] K. Mori, T. Hara, T. Mizugaki, K. Ebitani, K. Kaneda, J. Am. Chem. Soc., 2004, 126, 10657-10666.

[4] H. L. Wu, Q. H. Zhang, Y. Wang, Adv. Synth. Catal., 2005, 347, 1356-1360.

[5] F. Li, Q. H. Zhang, Y. Wang, Appl. Catal. A, 2008, 334, 217-226.

[6] P. F. Zhang, Y. T. Gong, H. R. Li, Z. R. Chen, Y. Wang, Nat. Commun., 2013, 4, 1593.

[7] Z. A. Qiao, P. F. Zhang, S. H. Chai, M. F. Chi, G. M. Veith, N. C. Gallego, M. Kidder, S. Dai, J. Am. Chem. Soc., 2014, 136, 11260-11263.

[8] N. Dimitratos, J. A. Lopez-Sanchez, D. Morgan, A. Carley, L. Prati, G. J. Hutchings, Catal. Today, 2007, 122, 317-324.

[9] M. Sankar, E. Nowicka, R. Tiruvalam, Q. He, S. H. Taylor, C. J. Kiely, D. Bethell, D. W. Knight, G. J. Hutchings, Chem. Eur. J., 2011, 17, 6524-6532.

[10] T. Homma, T. Kitaoka, Chem. Eng. J., 2016, 285, 467-476.

[11] B. Wang, M. Lin, T. P. Ang, J. Chang, Y. H. Yang, A. Borgna, Catal. Commun., 2012, 25, 96-101.

[12] Y. T. Chen, Z. Guo, T. Chen, Y. H. Yang, J. Catal., 2010, 275, 11-24.

[13] Y. B. Yan, Y. T. Chen, X. L. Jia, Y. H. Yang, Appl. Catal. B, 2014, 156-157, 385-397.

[14] Y. M. Lu, H. Z. Zhu, J. W. Liu, S. H. Yu, ChemCatChem, 2015, 7, 


\section{Graphical Abstract}

Chin. J. Catal., 2017, 38: 1870-1879 doi: 10.1016/S1872-2067(17)62904-8

\section{Selective suppression of toluene formation in solvent-free benzyl alcohol oxidation using supported Pd-Ni bimetallic} nanoparticles

Jianwei Che, Mengjia Hao, Wuzhong Yi, Hisayoshi Kobayashi, Yuheng Zhou, Liping Xiao, Jie Fan * Zhejiang University, China; Kyoto Institute of Technology, Japan

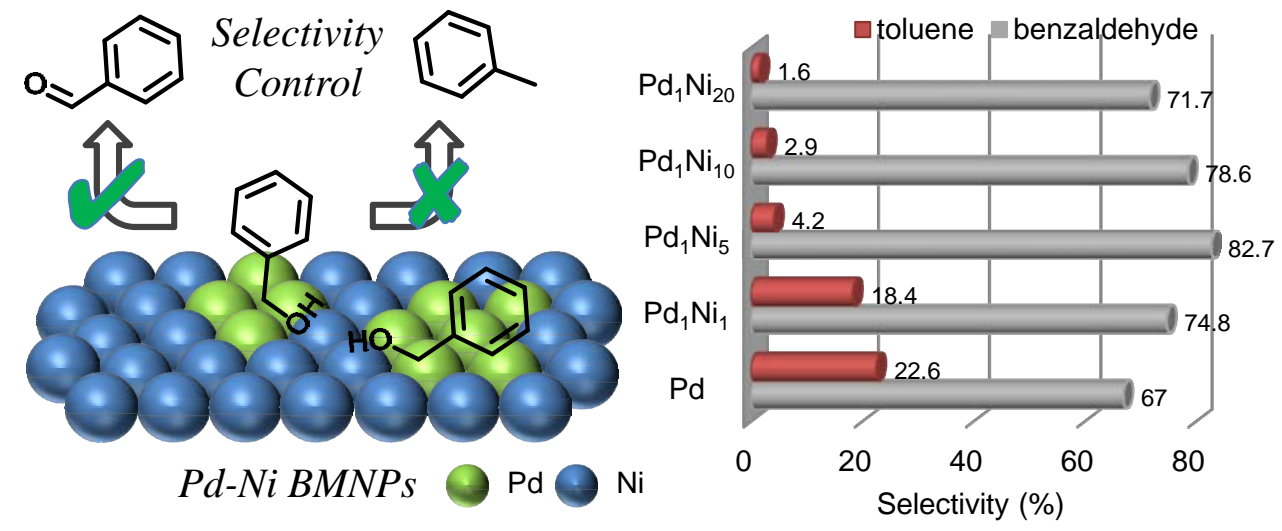

Supported Pd-Ni bimetallic nanoparticles prepared through a solid-state alloying method can enhance the selectivity towards benzaldehyde by effective suppression of toluene formation in a solvent-free benzyl alcohol oxidation reaction.

\section{1-4136.}

[15] D. I. Enache, J. K. Edwards, P. Landon, B. Solsona-Espriu, A. F. Carley, A. A. Herzing, M. Watanabe, C. J. Kiely, D. W. Knight, G. J. Hutchings, Science, 2006, 311, 362-365.

[16] D. I. Enache, D. Barker, J. K. Edwards, S. H. Taylor, D. W. Knight, A. F. Carley, G. J. Hutchings, Catal. Today, 2007, 122, 407-411.

[17] Q. He, P. J. Miedziak, L. Kesavan, N. Dimitratos, M. Sankar, J. A. Lopez-Sanchez, M. M. Forde, J. K. Edwards, D. W. Knight, S. H. Taylor, C. J. Kiely, G. J. Hutchings, Faraday Discuss., 2013, 162, 365-378.

[18] R. Ferrando, J. Jellinek, R. L. Johnston, Chem. Rev., 2008, 108, 845-910.

[19] A. K. Singh, Q. Xu, ChemCatChem, 2013, 5, 652-676.

[20] Y. Xu, L. Chen, X. C. Wang, W. T. Yao, Q. Zhang, Nanoscale, 2015, 7, 10559-10583.

[21] J. K. A. Clarke, Chem. Rev., 1975, 75, 291-305.

[22] F. Gao, D. W. Goodman, Chem. Soc. Rev., 2012, 41, 8009-8020.

[23] N. Tsubaki, S. L. Sun, K. Fujimoto, J. Catal., 2001, 199, 236-246.

[24] A. Yarulin, I. Yuranov, F. Cárdenas-Lizana, D. T. L. Alexander, L. Kiwi-Minsker, Appl. Catal. A, 2014, 478, 186-193.

[25] K. A. Goulas, S. Sreekumar, Y. Y. Song, P. Kharidehal, G. Gunbas, P. J. Dietrich, G. R. Johnson, Y. C. Wang, A. M. Grippo, L. C. Grabow, A. A. Gokhale, F. D. Toste, J. Am. Chem. Soc., 2016, 138, 6805-6812.

[26] D. J. Childers, N. M. Schweitzer, S. M. K. Shahari, R. M. Rioux, J. T. Miller, R. J. Meyer, J. Catal., 2014, 318, 75-84.

[27] M. Armbrüster, M. Behrens, F. Cinquini, K. Föttinger, Y. Grin, A. Haghofer, B. Klötzer, A. Knop-Gericke, H. Lorenz, A. Ota, S. Penner, J. Prinz, C. Rameshan, Z. Révay, D. Rosenthal, G. Rupprechter, P. Sautet, R. Schlögl, L. D. Shao, L. Szentmiklósi, D. Teschner, D. Torres, R. Wagner, R. Widmer, G. Wowsnick, ChemCatChem, 2012, 4, 1048-1063.

[28] S. J. Freakley, Q. He, J. H. Harrhy, L. Lu, D. A. Crole, D. J. Morgan, E. N. Ntainjua, J. K. Edwards, A. F. Carley, A. Y. Borisevich, C. J. Kiely, G. J. Hutchings, Science, 2016, 351, 965-968.
[29] T. Komatsu, K. Inaba, T. Uezono, A. Onda, T. Yashima, Appl. Catal. A, 2003, 251, 315-326.

[30] G. C. Ma, X. Q. Yan, Y. L. Li, L. P. Xiao, Z. J. Huang, Y. P. Lu, J. Fan, J. Am. Chem. Soc., 2010, 132, 9596-9597.

[31] R. Sato, M. Kanehara, T. Teranishi, Small, 2011, 7, 469-473.

[32] Y. Tang, S. D. Xu, Y. H. Dai, X. Q. Yan, R. H. Li, L. P. Xiao, J. Fan, Chem. Commun., 2014, 50, 213-215.

[33] M. C. Payne, M. P. Teter, D. C. Allan, T. A. Arias, J. D. Joannopoulos, Rev. Mod. Phys., 1992, 64, 1045-1097.

[34] V. Milman, B. Winkler, J. A. White, C. J. Pickard, M. C. Payne, E. V. Akhmatskaya, R. H. Nobes, Int. J. Quantum Chem., 2000, 77, 895-910.

[35] J. P. Perdew, K. Burke, M. Ernzerhof, Phys. Rev. Lett., 1996, 77, 3865-3868.

[36] J. P. Perdew, K. Burke, M. Ernzerhof, Phys. Rev. Lett., 1997, 78, 1396.

[37] D. Vanderbilt, Phys. Rev. B, 1990, 41, 7892-7895.

[38] J. Saha, K. Bhowmik, I. Das, G. De, Dalton Trans., 2014, 43, 13325-13332.

[39] C. Y. Du, M. Chen, W. G. Wang, G. P. Yin, ACS Appl. Mater. Interfaces, 2011, 3, 105-109.

[40] J. Zhao, A. Sarkar, A. Manthiram, Electrochim. Acta, 2010, 55, 1756-1765.

[41] K. S. Kim, N. Winograd, Chem. Phys. Lett., 1975, 30, 91-95.

[42] S. M. Foiles, M. I. Baskes, M. S. Daw, Phys. Rev. B, 1986, 33, 7983-7991.

[43] M. F. Zhou, L. Andrews, C. W. Bauschlicher, Chem. Rev., 2001, 101, 1931-1961.

[44] M. A. Matin, J. H. Jang, Y. U. Kwon, J. Power Sources, 2014, 262, 356-363.

[45] D. M. Meier, A. Urakawa, A. Baiker, J. Phys. Chem. C, 2009, 113, 21849-21855.

[46] N. Dimitratos, J. A. Lopez-Sanchez, D. Morgan, A. F. Carley, R. Tiruvalam, C. J. Kiely, D. Bethell, G. J. Hutchings, Phys. Chem. Chem. 
Phys., 2009, 11, 5142-5153.

[47] A. Savara, C. E. Chan-Thaw, I. Rossetti, A. Villa, L. Prati, ChemCatChem, 2014, 6, 3464-3473.

[48] P. Liu, J. K. Nørskov, Phys. Chem. Chem. Phys., 2001, 3, 3814-3818.

[49] B. Hammer, J. K. Nørskov, Adv. Catal., 2000, 45, 71-129.

[50] R. J. Hou, W. T. Yu, M. D. Porosoff, J. G. Chen, T. F. Wang, J. Catal.,
2014, 316, 1-10.

[51] A. Villa, D. Ferri, S. Campisi, C. E. Chan - Thaw, Y. Lu, O. Kröcher, L. Prati, ChemCatChem, 2015, 7, 2534-2541.

[52] S. Y. Shan, V. Petkov, L. F. Yang, J. Luo, P. Joseph, D. Mayzel, B. Prasai, L. Y. Wang, M. Engelhard, C. J. Zhong, J. Am. Chem. Soc., 2014, $136,7140-7151$

\title{
负载型Pd-Ni双金属纳米颗粒在无溶剂苯甲醇氧化中有效抑制甲苯的生成

\author{
车建伟 ${ }^{\mathrm{a}}$, 郝梦佳 ${ }^{\mathrm{a}}$, 易武中 ${ }^{\mathrm{a}}$, Hisayoshi Kobayashi ${ }^{\mathrm{b}}$, 周宇恒 ${ }^{\mathrm{a}}$, 肖丽萍 ${ }^{\mathrm{a}}$, 范 杰, ${ }^{\mathrm{a},{ }^{*}}$ \\ $a^{a}$ 浙江大学化学系浙江省应用化学重点实验室, 浙江杭州 310027 \\ b 京都工艺纤维大学, 日本京都606-8585
}

\begin{abstract}
摘要: 醇类化合物的选择性氧化是实验室和工业应用中一类重要的官能团转化反应. 以分子氧为氧化剂, 在液相无溶剂条 件下温和氧化符合绿色化学的要求. 负载型Pd基催化剂因其优异的催化活性而在该反应中得到广泛应用. 但是, 单金属Pd 催化剂对反应目标产物醛类化合物的选择性还有待提高. 例如, 在苯甲醇液相无溶剂氧化中, 甲苯是在单金属Pd催化剂上 的主要副产物. 针对这一问题, 除了对载体进行改性和修饰外, 开发双金属Pd基催化剂也是一种有效的选择性调控策略. 虽然已有的Pd-Au双金属催化剂可以在一定程度上降低甲苯的选择性, 但是在较高温度和较高转化率下仍然难以控制甲苯 的大量生成.

本文采用固相合金化法合成了负载型Pd-Ni双金属纳米颗粒.该方法首先以硝酸镍为镍的前驱体浸渍介孔二氧化硅, 然后负载钯纳米颗粒. 在高温固相还原条件下, 作为种子的钯纳米颗粒和镍通过原子迁移和生长, 形成Pd-Ni双金属纳米颗 粒. 扫描透射电镜、能量色散X射线光谱、X射线衍射和X射线光电子能谱等表征证实了 Pd-Ni双金属纳米颗粒的生成. 上 述催化剂用于苯甲醇液相无溶剂氧化, 催化结果显示 $\mathrm{Ni}$ 的加入可以抑制副产物甲苯的生成, 并且随 $\mathrm{Ni}$ 负载量增加, 甲苯的 选择性(在 $80 \%$ 等转化率下)由 $22.6 \%$ (单金属Pd)降低至1.6\%(双金属 $\mathrm{Pd}_{1} \mathrm{Ni}_{20}$ ). 尽管 $\mathrm{Ni}$ 的加入降低了单金属Pd的活性, 但是由 于提高了目标产物苯甲醛的选择性, 酫的最终产率得到提升. 进一步催化研究表明, Ni的加入可以抑制无氧氛围下甲苯的 生成, 说明 $\mathrm{Ni}$ 可以抑制歧化反应和降低表面氢浓度. 这种作用可归结于Pd-Ni双金属的协同效应. 该效应得到了CO吸附的 傅里叶变换漫反射红外光谱和密度泛函理论研究的证实. 双金属的几何效应和电子效应均减弱了苯甲醇在双金属纳米颗 粒表面的解离吸附和相互作用, 导致苯甲醇的吸附减弱, 同时 C-O键断裂不易进行. 另外, 由于 $\mathrm{Ni}$ 的亲氧性, 双金属纳米颗 粒表面有利于氧的吸附, 降低吸附氢的浓度, 减少 $\mathrm{C}-\mathrm{H}$ 键生成, 从而抑制甲苯的生成.
\end{abstract}

关键词: 钯-镍; 双金属纳米颗粒; 苯甲醇; 甲苯; 无溶剂; 氧化

收稿日期: 2017-07-12. 接受日期: 2017-08-13. 出版日期: 2017-11-05.

*通讯联系人. 电话/传真: (0571)87952338; 电子信箱: jfan@zju.edu.cn

基金来源：国家自然科学基金(21271153，21373181，21222307，U1402233); 国家自然科学基金重大研究计划(91545113); 中央高 校基本科研业务费专项资金(2014XZZX003-02).

本文的电子版全文由Elsevier出版社在ScienceDirect上出版(http://www.sciencedirect.com/science/journal/18722067). 